\title{
Behavioral Characteristics of Photovoltaic Cell with Different Irradiation in Matlab/Simulink/Simscape Environment
}

\author{
Hamisu Usman \\ S. M. Lawal \\ R. S. Shehu
}

Dept of Electrical \& Electronics Engineering, College of Engineering, Kaduna Polytechnic Kaduna

Doi:10.5901/ajis.2014.v3n7p55

\begin{abstract}
Photovoltaic technology is one of the fastest growing energy among the different type of renewable energies that are available for electricity generation. This is due to the availability of the natural sun rise, and the non polluted energy that is free from emission of carbon dioxide $\left(\mathrm{CO}_{2}\right)$. This paper presents a typical modeling of photovoltaic cell under different irradiations level, in order to monitor the behavior of the (Voltage-Current) V-I and (Power-Voltage) P-V characteristics. The simulation of the proposed model was performed in MATLAB/SIMULINK and Simscape environment. Single diode model of the PV system was presented in the mathematical modeling of the proposed system. Simulation results of different I-V and P-V characteristics were also presented.
\end{abstract}

Keywords: Photovoltaic, Irradiant, Temperature, V-I and P-V curves.

\section{Introduction}

The advancement of PV technology in the recent years has made solar technology a suitable source of energy in the world market. Photovoltaic energy generation seems to be the most popular and reliable source of energy generation among the types of available renewable energies. PV systems exhibit a low generation of carbon dioxide $\left(\mathrm{CO}_{2}\right)$, which is free from polluting the environment. Report in (Tariq, Asim, \& Tariq, 2011), predicted in 2035 the combined intermittent non-dispatch able energy generation are expected to reach $4 \%$ of the total energy generation. The energy generated by PV systems is purely clean, with high reliability and durability in service (Besh, Khater, \& Abdelraouf, 2010). With the advancement of technology, and high demand of PV cells, the PV prices are now considerably reduced due to the advancement of film technology and the manufacturing process(Bhubaneswar, \& Annamalai, 2011). Materials that are employed in the photovoltaic cells for all types of PV (s) are monocrystalline silicon, polycrystalline silicon, microcrystalline silicon, cadmium telluride and copper indium Selenide (Maheshappaet, Nagaraju, \&Krishna, 1998). Many literatures as in(John et al., 2011), (Ramos-Hernanz et al 2013), (Jacob, Chan, \& Philips, 1984), a simple one diode model with different solar isolation variation has been studied and the effect of series resistance were also investigated. While, (Oleg, 1983), (Rhonda, Ghassemi, \& Cota, 2010), (Sushen, 2010), compared the simulation model of a single and double diodes photovoltaic system in simscape environment which validates the V-I and P-V characteristics. The inception of computer simulation in PV mathematical modeling has been in practice for the past four decades(Stanley, 1982), (Tsai, Ci-Siang, \& Yi-Jie, 2008), (Tarak, Bouzgueda, \& Gastli, 2012). In this paper, modeling of an equivalent single diode solar cell in order to study the behavior of the V-I and P-V characteristics is presented. Simulation results of the $\mathrm{V}-\mathrm{I}$ and $\mathrm{P}-\mathrm{V}$ curves under different irradiance are also presented in this study.

\section{One Diode Photovoltaic Cell Model}

Fig. 1. Below, depicts the circuit equivalent model of a single diode PV cell. As it can be seen by the diagram, it comprises of current source, diode, shunt and series resistances respectively (Weidong, Edwin, Spagnuolo \& Jatskevich, 2013). 


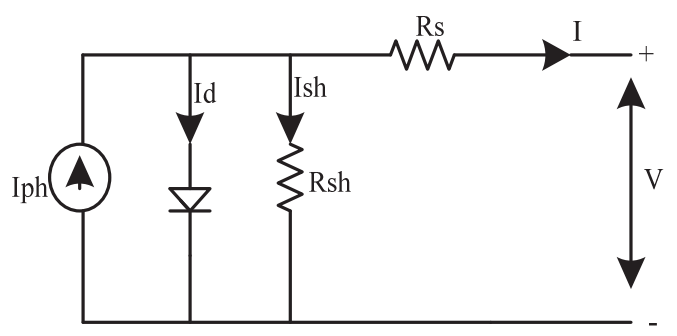

Fig. 1. One Diode PV cell Equivalent Circuit

An equation which represents the current to the load based on Fig. 1. Can be writing as in equation (1).

$I=I_{p h}-I_{s}\left[\exp \frac{q\left(V+R_{s} I\right)}{N K T}-1\right]-\frac{\left(V+R_{s} I\right)}{R_{s h}} \ldots . . .(1)$

Where:

$I_{p h}=$ Photo current in (A)

$I_{s}=$ Reverse saturation current in $(\mathrm{A})$

$q=$ Electron charge $\left(=1.602^{\star} 10^{-19}\right)$

$V=$ Voltage across the diode in $(\mathrm{V})$

$K=$ Boltzmann's Constant $\left(=1.381 * 10^{-23} \mathrm{~J} / \mathrm{K}\right)$

$T=$ Junction temperature in (Kelvin)

$N=$ Ideality factor of the diode

$R_{s}=$ Series resistance in $(\Omega)$

$R_{s h}=$ Shunt resistance in $(\Omega)$

Based on equation (1), the MATLAB/SIMULINK model can be simulated as depicted in (Wang, Mei, \& Guosheng, 2011), but in this paper, we modeled the PV system in Sims cape environment as the novelty of this paper.

\section{SIMULINK/ SIMSCAPE Model of Photovoltaic Cell}

Fig. 2.Shows the simscape model of a solar cell which is available in the library browser of the MATLAB/Simelectronic environment.

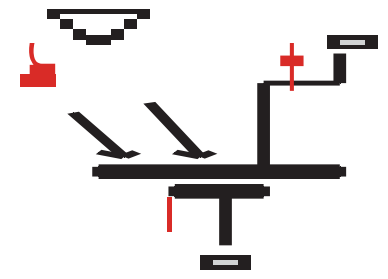

Fig. 2. Solar Cell block in Simscape Environment

Solar cell is a block models which comprises of combination of current source in parallel with two exponential diodes and parallel resistor that are connected in series with resistance. In Fig.2.a signal input $I_{r}$ which is the irradiance (light intensity) measured in W/m² falling on the cell. In view of this process, the solar-generated current ${ }^{I_{p h}}$ is given by the expression given as ${ }^{I_{r} \times\left(\frac{I_{p h o}}{I_{r o}}\right)}$. Where $I_{p h o}$ is the measured solar-generated current for irradiance ${ }^{I_{r o}}$.

\section{Complete MATLAB/SIMSCAPE Modeling of the Photovoltaic Cell}

A simple circuit design of the MATLAB/SIMSCAPE model of the proposed simulation model is depicted in Fig. 3 . This circuit comprise of variable resistance which is connected across the solar cell. Unit ramp signal from the MATLAB library browser was employed in order to vary the value of the variable resistance from the initial zero position to its maximum 
value by the resistor. The open circuit and short circuit values can be generated at the terminals of the solar cell, the V-I and P-V characteristics curves of the simulation results that can be obtained. In the simulation model, a constant block was used in order to vary the value of the irradiation from $200 \mathrm{~W} / \mathrm{m}^{2}$ to the maximum value of $1000 \mathrm{~W} / \mathrm{m}^{2}$ specified by the manufacturer's data sheetof any photovoltaic cell. In similar vein, V-I and P-V scopes were also utilized for the display of the V-I and P-V characteristics curves.

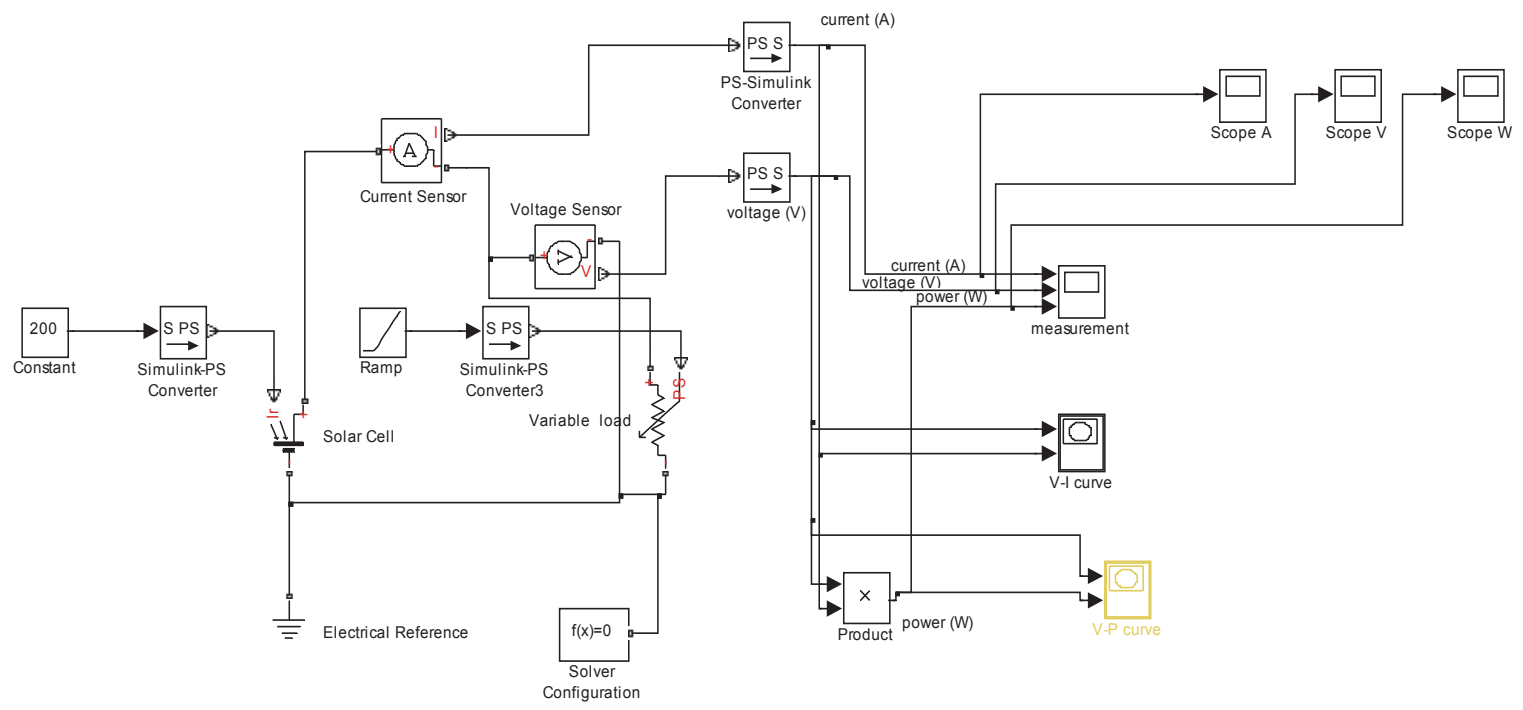

Fig. 3. Complete MATLAB/SIMULINK/SIMSCAPE Simulation Model

\section{Results and Discussion}

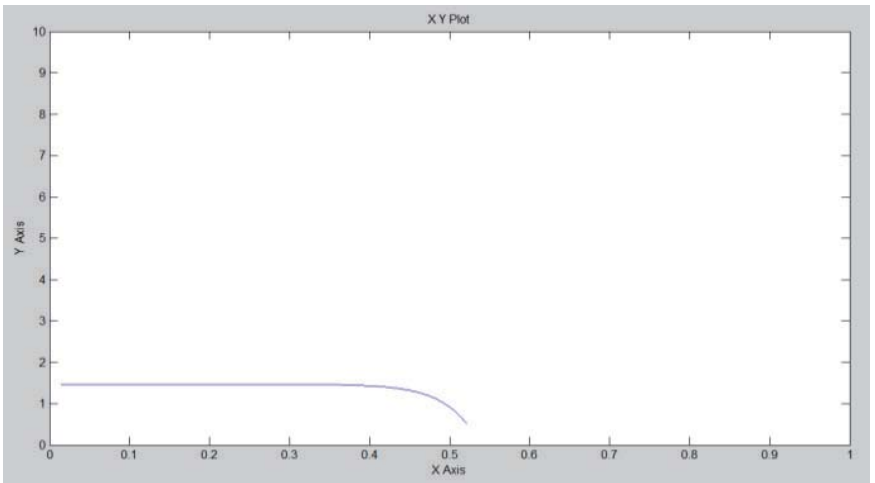

Fig. 4. I-V Characteristic Curve at 200W/m²

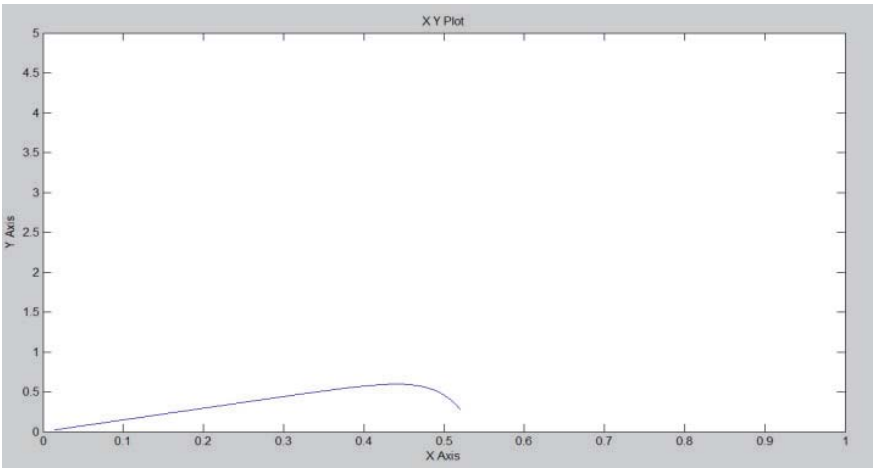

Fig. 5. P-V Characteristic Curve at $200 \mathrm{~W} / \mathrm{m}^{2}$ 


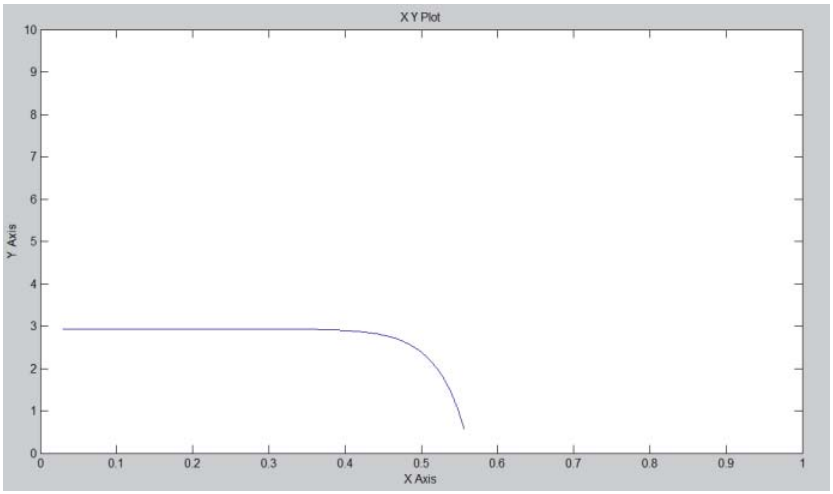

Fig. 6. I-V Characteristic Curve at $400 \mathrm{~W} / \mathrm{m}^{2}$

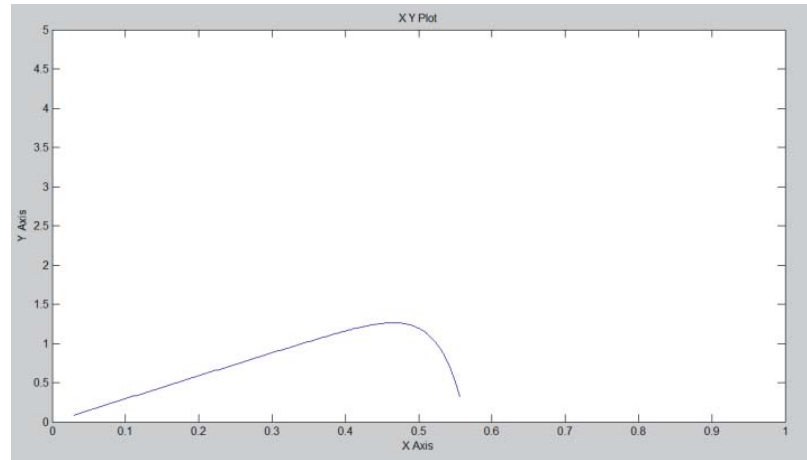

Fig. 7. P-V Characteristic Curve at $400 \mathrm{~W} / \mathrm{m}^{2}$

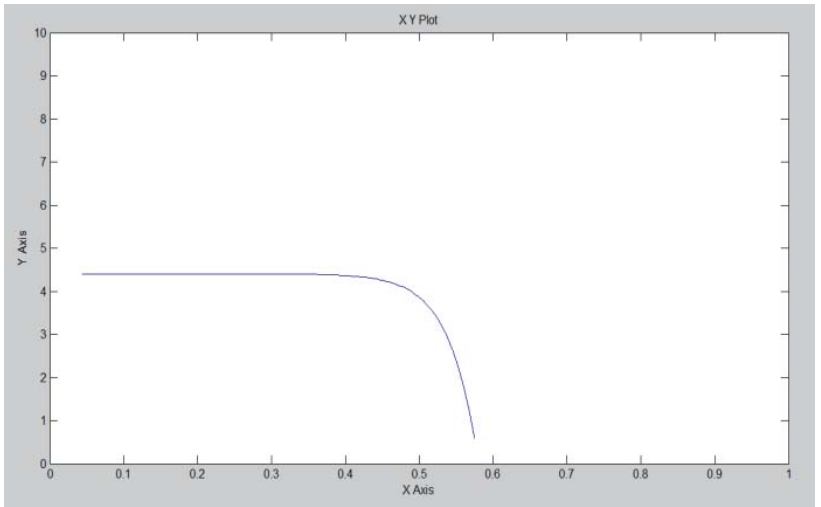

Fig. 8. I-V Characteristic Curve at $600 \mathrm{~W} / \mathrm{m}^{2}$

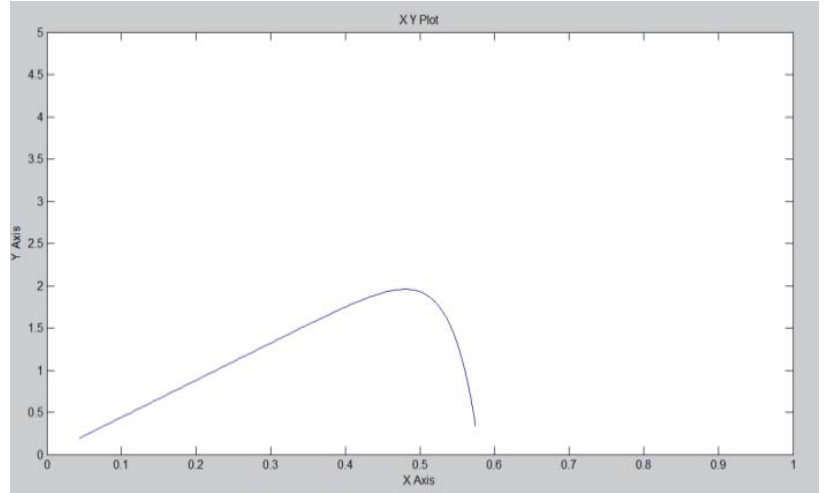

Fig. 9. P-V Characteristic Curve at $600 \mathrm{~W} / \mathrm{m}^{2}$ 


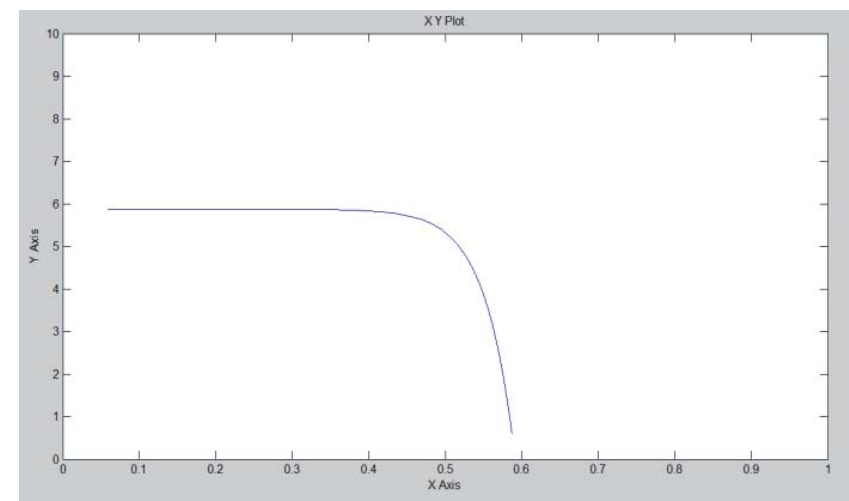

Fig. 10. I-V Characteristic Curve at $800 \mathrm{~W} / \mathrm{m}^{2}$

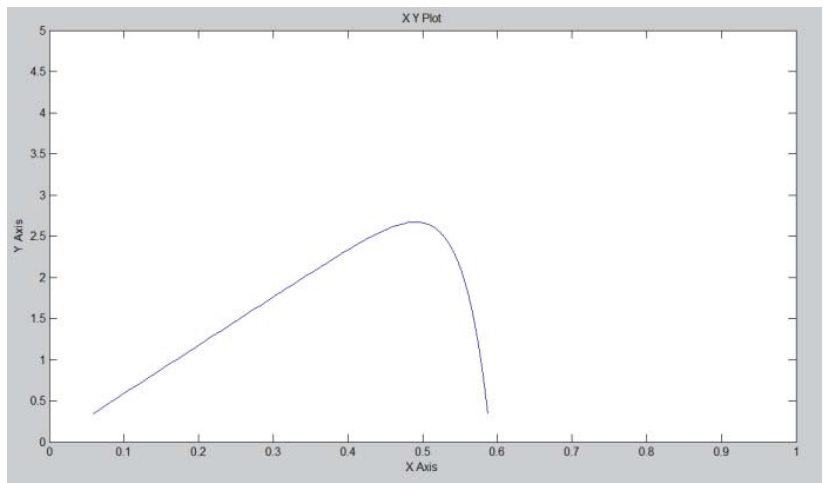

Fig. 11. P-V Characteristic Curve at $800 \mathrm{~W} / \mathrm{m}^{2}$

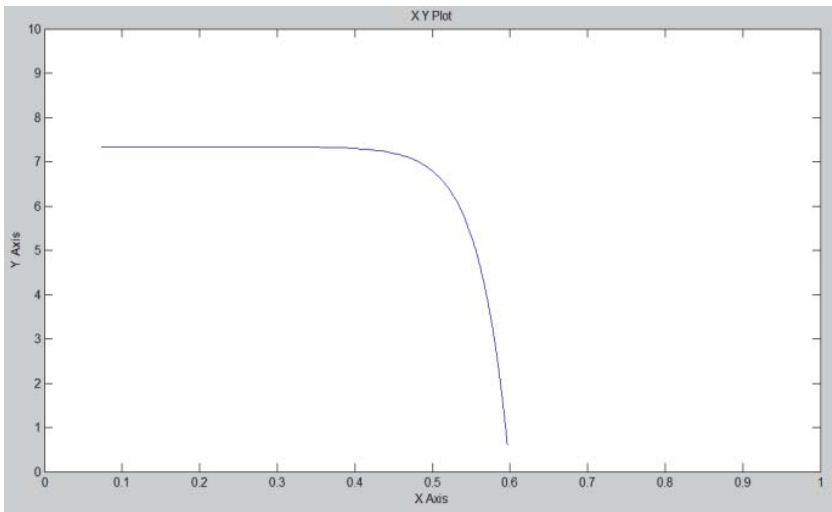

Fig.12. I-V Characteristic Curve at $1000 \mathrm{~W} / \mathrm{m}^{2}$

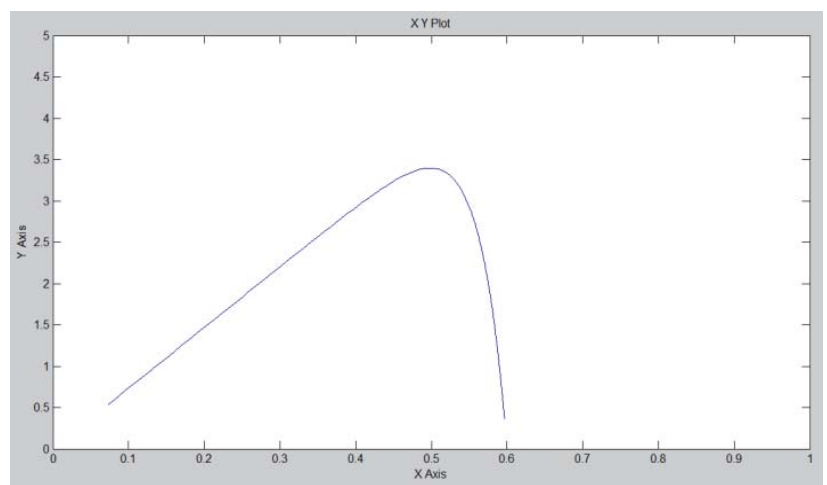

Fig. 13. P-V Characteristic Curve at $1000 \mathrm{~W} / \mathrm{m}^{2}$ 
Fig. 4-13 depicts the results in MATLAB/SIMSCAPE environment of the output characteristics of I-V and P-V curves respectively. Solar irradiation of $200 \mathrm{~W} / \mathrm{m}^{2}$ to $1000 \mathrm{~W} / \mathrm{m}^{2}$ specified by the manufactures data sheet was adopted in the simulation study. From all the figures 4-13 in the discussion study, the maximum power point (MPP) based on the selected irradiations on P-V characteristic curves and I-V curves were attained. This means that, the lower the irradiation the lower the characteristic curves, while the higher the irradiance the better the characteristics curves.

\section{Conclusion}

The principle modeling of photovoltaic cell based on MATLAB/SIMULINK/SIMSCAPE environment with different solar irradiations is presented in this paper. The behaviors of the characteristic curves under various solar irradiances are also investigated in this work. The simulation results revealed that, the higher the solar irradiance the better the output of the $\mathrm{V}-\mathrm{I}$ and P-V curves, and the lower the irradiance the lower the power output. The simulation results are in conformity with the solar modules manufacturer data sheet specifications.

\section{References}

Abu, T., Asim, M., \& Tariq, M. (2011). Simulink based modeling , simulation and PerformanceEvaluation of an MPPT for maximum power generation on resistive load, 6, 397-401.

Besh, M., Khater, K., Abdelraouf, H. A. (2010). Modeling of Residential Solar Stand alone PowerSyste, Nuclear \& Renewable Energy Conference (INREC), 1'st International Conference, pp. 1-6.

Bhuvaneswari, G., Annamalai, R. (2011). Development of a Solar Cell Model in MATLAB for PVBased Generation Syste, Annual IEEE India Conference (INDICO), pp. 1-5.

H. D. Maheshappa, J. Nagaraju., M. V. Krishna Murthy. (1998). An Improved Maximum PowerPoint Tracker using Step-up Converter with Current Locked Loop", Renewable Energy, Vol. 13, no. 2,pp. 195 -201.

John, J., et al, (2011). Annual Energy outlook 2011 with Projection s to 2035", Technical Report, U. S.Energy Information Administration, pp. 1-236.

JA.Ramos-Hernanz, Campayo, J. J., Zulueta, E., Barambones, O., Equia, P., Zamora, I. (2013).Obtaining the Characteristics Curves of a Photovoltaic by Different Method, International Conference onRenewable Energies and Power Quality (ICREPQ 13), no. 11,

Jacob, Phang C. H., Chan, D. S. H., Philips, J. R. (1984). Accurate Analytical Method for theExtraction of Solar Cell Model Parameters", Electronics Letters, Vol. 20, no. 10, pp. 406-408

Oleg, W. (1983). Dynamic Behavior of a Class of Photovoltaic Power Systems, IEEE Transactions onPower Appratus and Systems, Vol. PAS-102, no. 9, pp. 3031-3037.

Rhonda, Foster., Ghassemi, M., Cota, A. (2010). Solar Energy:Renewable Energy and theEnvironment, 2010 Boca Raton, CRC Press.

Sushen, N., (2010). Modeling of Photovoltaic Array, Btech. Thesis, National Institute of TechnologyRourkela, Orissa. 2010, pp. 1-35

Stanley, Angrist, W., Direct Energy Conversion, Allyn and Bacon, Inc, $4^{\text {th }}$ Edition, 1982, pp. 177227

Tsai.Huan-Liang, Ci-Siang, T., Yi-Jie, S. (2008). Development of Generalized Photovoltaic Modelusing MATLAB/SIMULIN, Proceeding of the World Congress on Engineering and Computer Science(WCECS), San Francisco, U. S. A.

Tarak, S., M. Bouzgueda, A., Gastli, Masmoudi, A. (2012). MATLAB/SIMULINK Based Modelingof Solar Photovoltaic Cell, International Journal of Renewable Energy Research, Vol. 2, no. 2, pp.1-6

Weidong, Xiao., Edwin, F. F., Spagnuolo, G., Jatskevich, J. (2013). Efficient Approachs forModeling and Simulating Photovoltaic Power System, IEEE Journal of Photovoltaic, Vol. 3, Issue 1, pp.500-508

Wang, Nianchun., Mei Yue, W. S., Guosheng, S. (2011). Study on Characteristics of PhotovoltaicCells Based on MATLAB Simulation, Power and Energy Engineering Conference (APPEEC), 2011 AssiaPacific, pp. 1-4 